\title{
Application of modified qualitative index for surveillance of water-filtration process in turbidity removal by different media
}

\author{
G. Badalians Gholikandi $\cdot$ M. Noorisepehr • \\ E. Dehghanifard · A. Koolivand · A. Dehnavi • \\ S. Moalej
}

Received: 28 December 2010/Revised: 25 July 2011/Accepted: 30 November 2011/Published online: 27 March 2012

(C) CEERS, IAU 2012

\begin{abstract}
Several media have been used in treatment plants, however, their efficiency for turbidity removal, which is determined by qualitative indices, has been considered. Current qualitative indices such as turbidity and escaping particle number could not completely measure the efficiency of the filtration system; therefore defining new qualitative indices is essential. In this study, the efficiency of two different dual media filters in turbidity removal was compared in different operating condition using qualitative indices. The pilot consisted of a filter column (1-m depth) in which the filter-1 was consisted of a layer of anthracite (450-mm depth) and a layer of silica sand (350-mm depth); and filter-2 had the same media characteristics except for the first layer that was light expanded clay aggregates (LECA). Turbidities of 10, 20, and 30 NTU, coagulant concentrations of 4,8 , and $12 \mathrm{ppm}$ and filtration rates of
\end{abstract}

G. Badalians Gholikandi

Power and Water University of Technology (PWUT),

Tehran, Iran

M. Noorisepehr $(\bowtie) \cdot$ E. Dehghanifard

Department of Environmental Health Engineering,

School of Public Health, Alborz University of Medical Sciences,

Karaj, Alborz, Iran

e-mail: golnara2006@yahoo.com

A. Koolivand

Department of Environmental Health Engineering,

School of Public Health, Tehran University of Medical Sciences,

Tehran, Iran

A. Dehnavi

Department of Environment Civil Engineering, School of Civil

Engineering, Tarbiat Modares University, Tehran, Iran

S. Moalej

Tehran Water and Wastewater Company (ABFA), Tehran, Iran
10,15 , and $20 \mathrm{~m} / \mathrm{h}$ were considered as variables. Results showed that the media of filter- 2 is a suitable substitute for the media of filter-1 $(P$ value $<0.05)$. Turbidity removal efficiencies in different condition were $79.97 \pm 1.79$ to $91.37 \pm 1.23 \%$ for the filter- 2 and $75.12 \pm 2.75$ to $86.82 \pm 1.3 \%$ for the filter-1. The LECA layer efficiency in turbidity removal was independent of filtration rates and due to its low head loss; LECA can be used as a proper medium. Results also showed that the particle index was a suitable index as a substitute for turbidity and escaping particle number as indices.

Keywords Anthracite - Dual media filter - Light expanded clay aggregates $\cdot$ Silica $\cdot$ Turbidity

\section{Introduction}

The filtration processes are used primarily to remove particulate material from water. Filtration is one of the unit processes used in the production of potable water. Removed particulates may be those already present in water source or those formed during treatment processes (AWWA 2004; Baruth 2005; Taghizadeh et al. 2007). Examples of particulates include clay and silt particles; microorganisms (bacteria, viruses, and protozoan cysts); colloidal and precipitated humic substances and other natural organic particulates from vegetation decay; precipitates of aluminum or iron used in coagulation; calcium carbonate and magnesium hydroxide precipitates from lime softening; and iron and manganese precipitates (Davis 2010; Hammer 2011).

Selection of type and characteristics of filter media, that is the heart of a filtration system, is usually based on arbitrary decisions, tradition, or a standard approach. Pilot plant studies using alternative filter media and filtration 
rates can determine the most effective and efficient media for a particular water (Kawamura 2000).

The removal of suspended solids by the filter media involves two separate and distinct steps: transport of suspended particles to the solid-liquid interface presented by the filter and attachment of particles to this surface (Pawlowicz et al. 2006; Templeton et al. 2007). Some material already deposited on the medium can be detached due to increased shearing forces resulting from filter clogging. Straining becomes a dominant removal mechanism when the ratio of the particle size to media grain size is greater than $0.2 \mu \mathrm{m}$ (Johnston 1999) and for the particles which are greater than $100 \mu \mathrm{m}$ (Tansel and Vinal 2005; Devi et al. 2008). Straining is undesirable during granular media filtration, due to the formation of a surface layer, rapid head loss increase (Zouboulis et al. 2007). Filter ripening is the improvement of the removal efficiency with time after backwash. In this mechanism, retained particles provide additional removal possibility for the suspended particles. Although the particle size and distribution would change with the filter depth, the head loss within the filter is directly related to the surface area of captured particles (Brogowski and Renman 2004; Tansel and Vinal 2005; Roque-Malherbe 2007).

Selection of the type and characteristics of filter media that is the heart of a filtration system is usually based on arbitrary decisions, tradition, or a standard approach. Pilot plant studies using alternative filter media and filtration rates can determine the most effective and efficient media for a particular water (Kawamura 2000).

The common types of media used in granular bed filters are silica sand, anthracite coal, and garnet or ilmenite (Mitrouli et al. 2009; Moazed and Viraraghavan 2002; Hatt et al. 2007). These may be used alone or in dual- or triplemedia combinations; a number of properties of a filter medium are important in affecting the filtration performance and also in defining the medium. These properties include size, shape, density, and hardness. The porosity of the granular bed formed by the grains is also important (Moazed and Viraraghavan 2002; AWWA 2004).

Many studies have been done on filters media for enhancing treated drinking water (El-Taweel and Ali 2000; Melin et al. 2000; Babu and Chaudhuri 2005; Pawlowicz et al. 2006).

In general, turbidity is considered as a common index for filtration efficiency determination; however, this index is weak for the particles with 1-10 $\mu \mathrm{m}$ diameter including pathogen microorganisms. Along with the escaped particle number (EPN), turbidity is used to control filtration efficiency, nevertheless these indices are not satisfactory (Kawamura 2000).

Some studies have been conducted to evaluate the performance of filter media on removal of different pollutants from water and wastewater (Templeton et al. 2007; Devi et al. 2008; Remize et al. 2009; Fuerhacker et al. 2011; Ho et al. 2011). In these studies, however, no efficient indices have been applied to evaluate the performance of filter media and to compare the efficiencies of different media.

Some studies have been conducted to evaluate the performance of filter media on removal of different pollutants from water and wastewater (Johnston 1999; Templeton et al. 2007; Tansel and Vinal 2005; Williams et al. 2007; Devi et al. 2008; Remize et al. 2009; Malakootian 2009). In these studies, however, no efficient indices have been applied to evaluate the performance of filter media and to compare the efficiencies of different media. Light expanded clay aggregates (LECA) has been considered as a media for water filtration due to its characteristics such as high adsorption capacity, abundant resources, inexpensive in compare to other media and etc, however most of studies were applied LECA as an adsorbent (Amiri et al. 2011; Malakootian 2009; Roque-Malherbe 2007). This study was conducted to evaluate the efficiency of the LECA, anthracite and silica media in dual-layer filters in multiple operating conditions using turbidity. Suitability of the EPN and particle index (PI) as new indices for evaluation of the filter efficiency were also studied. This study was done in the water and wastewater laboratory of Power and Water University of Technology, Iran in 2009.

\section{Materials and method}

Filter

The pilot used in this study consisted of several units such as artificial turbidity injector, chemical coagulant injector and flash mixer, coagulant, flow meter, two dual-media filters with anthracite-silica and LECA-silica media, and filter backwash. Details have been shown in Fig. 1.

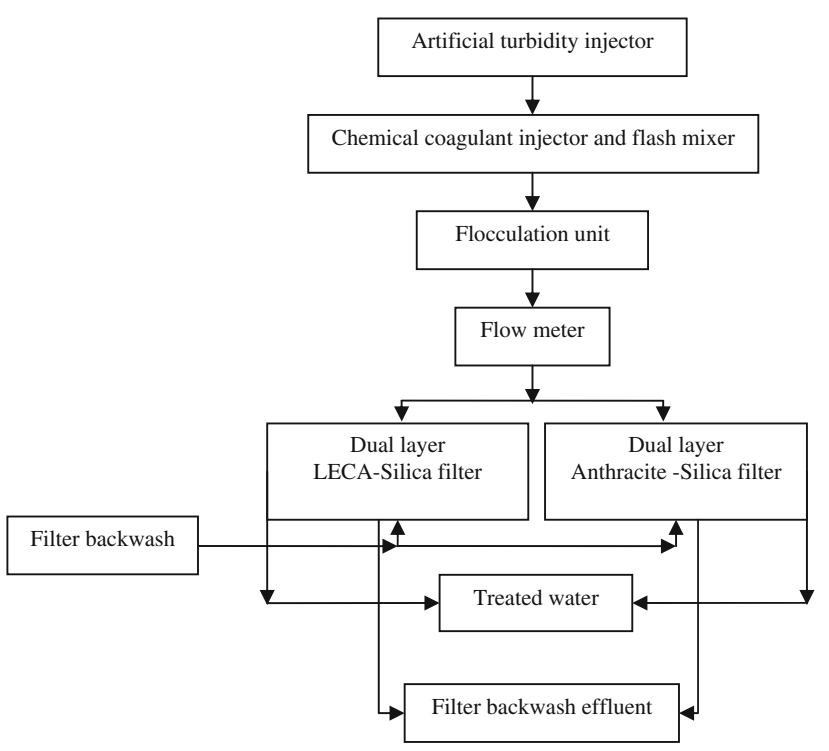

Fig. 1 Pilot diagram of dual media anthracite-silica and LECAsilica filters 


\section{Artificial turbidity injector}

This unit was consisted of a turbidity stock solution tank and stable height tank for water storage with specified turbidity to inject in the next unit. The stock solution tank was made of polyethylene with total and net capacity of 80 and $50 \mathrm{~L}$, respectively, and equipped with a $1,450 \mathrm{rpm}$ electromechanical mixer and a dosing pump for injecting turbidity solution to a stable tank. The stable height tank was made of polyethylene with 500-L capacity and equipped with an afloat, a 1,450 rpm electromechanical mixer and a globe valve. The municipal drinking-water pipe was connected to this tank and stock turbidity solution with a specified dose was straightly injected to the tank such that the final solution had a stable turbidity. By means of a globe valve, the effluent of this tank was conducted to the chemical coagulant injector and flash mixer.

Chemical coagulant injector and flash mixer unit

This unit was consisted of a flash mixing tank, a variable rate mixer and a mixer wing (shovel). The flash mixing tank was made of Plexiglas with a quadrangle section and 15.6-L capacity and special actions were done to prohibit short circuiting. The mixer used for this tank was a variable rate with average $1,450 \mathrm{rpm}$ having two-blades shovel flat wing and the 4:1 length to width ratio. In regard to retention time and velocity gradient in mixing tank, the mixing rate used in this study was $250 \mathrm{rpm}$.

\section{Flocculation unit}

This unit is consisted of three parts including flocculation tank, the variable rate mixer and mixing wing. The flocculation tank was made of polyethylene with a net volume of $300 \mathrm{~L}$ having a $0-650 \mathrm{rpm}$ variable rate mixer.

\section{Flow meter unit}

The flow meter used in this study was consisted of a Plexiglas tank having inlet, regulator, flow conductor to filter and backwash water effluent parts. A $30^{\circ}$ triangle-channel section was used to regulate the quantity of water entered to filters and excess water was collected by a separate pipe. The considered water quantities of this study for each filter were $5.24,7.86$ and $10.48 \mathrm{~L} / \mathrm{min}$ yielding filtration rates equal to 10,15 and $20 \mathrm{~m} / \mathrm{h}\left(\mathrm{m}^{3} / \mathrm{m}^{2} \mathrm{~h}\right)$, respectively.

Dual media filter

Filters used in this study had several parts including filter column, filtration-rate regulator, head-loss monitoring system, and filter media. To explain filters that were used in this study, the detailed specifications were noticed in the next section.

Filter column

Filter columns were made of Plexiglas with 200-mm internal diameter and 2-m height. The column diameter was selected to decrease the effects of column walls on the filter efficiency. The filter column was consisted of two $1 \mathrm{~m}$ columns that were joined and sealed by means of some flanges made of column materials. The required instruments such as head loss measurer, sampling valves and backwash accessories were installed properly.

\section{Filtration rate regulator}

The filtration rate regulator used in this study was a stable head and quantity type. For obtaining this condition, a $120 \mathrm{~L}$ tank and a floated valve were used. By artificial head creation in the length of filter, this tank provided head and outlet quantity stability. In effect, the stability of filtration rate was achieved.

\section{Head-loss monitoring system}

For measuring the head loss in filter columns, seven manometers and a manual gauge were used in each filter. Table 1 shows manometer depths that were installed on filter column.

Filter media

Filter media in filter-1 was consisted of one layer of anthracite with 450-mm depth and one layer of silica sand with $350-\mathrm{mm}$ depth. Filter-2 had the same media characteristics except for the first layer that was LECA. A support layer of silica gravel with $200-\mathrm{mm}$ depth was also used in each filter. The detailed specification of filter media has been shown in Table 2 .

Table 1 Manometer depths of filter columns

\begin{tabular}{lrrrrrrr}
\hline Manometer no. & 1 & 2 & 3 & 4 & 5 & 6 & 7 \\
Depth from bed surface (cm) & 10 & 20 & 30 & 40 & 55 & 70 & 80 \\
\hline
\end{tabular}

Table 2 Filter media specifications

\begin{tabular}{lllll}
\hline $\begin{array}{l}\text { No. } \\
\text { type }\end{array}$ & $\begin{array}{l}\text { Ledia } \\
(\mathrm{mm})\end{array}$ & $\begin{array}{l}\text { Uniformity } \\
\text { coefficient }\end{array}$ & $\begin{array}{l}\text { Effective } \\
\text { size }\end{array}$ \\
\hline 1 & LECA & 450 & $\approx 1$ & 2.14 \\
& Silica & 350 & 1.4 & 0.9 \\
2 & Anthracite & 450 & $\approx 1$ & 2.14 \\
& Silica & 350 & 1.4 & 0.9 \\
\hline
\end{tabular}




\section{Backwash accessories}

The backwash method of this study was up flow water wash with air scour. By application of AWWA related equation (AWWA 2004), water quantity for filter backwash was determined $35 \mathrm{~L} / \mathrm{min}$. The backwash system was similar for both filters. For uniform distribution of water and air currents in backwash phase, a Plexiglas plate with $3 \mathrm{~mm}$ pores was installed in the bottom of the filter, and was also wrapped by aluminum net to prevent particle escaping. In backwash phase, water and air currents were entered to the filter by two independent pipes with 1 and 0.5 in. diameter, respectively. The backwash phase was continuing until the system head loss reached $200 \mathrm{~mm}$, and backwash effluent was gathered at the end of the phase.

\section{Sample characteristics}

Inlet turbidity, coagulant concentration and filtration rate were the most important variables of this study. The inlet turbidity was produced by adding clay of 200 meshes. In addition, ferric chloride was used as the coagulant agent.

In this study, turbidities of 10, 20, and 30 NTU, coagulant concentrations of 4,8 , and $12 \mathrm{ppm}$ and filtration rates of 10,15 , and $20 \mathrm{~m} / \mathrm{h}$ were considered as variables. The filtration rates of 10 and $15 \mathrm{~m} / \mathrm{h}$ were chosen as filtration rates of water treatment plants and the $20 \mathrm{~m} / \mathrm{h}$ for critical conditions. Coagulant concentrations were selected by jar test and based on different inlet turbidity. All operating conditions adjusted similarly for both filters to compare the considered filters better.

\section{Sampling methods and analysis}

Samplings were done from 30-cm depth of LECA and anthracite layers of both filters for efficiency determination of those media, and at the water outlet for efficiency determination of total system. Samples were gathered from 1-mm diameter valves to prevent a turbulence condition in filter media. Head-loss measurements were done in sampling valves.

All sampling methods and analysis were done in accordance with the standard methods for the examination of water and wastewater (APHA 2005). Samples turbidities were measured by portable turbidity meter HACH-2100 and the escaping particles were analyzed by diameter measurer LATS-1 (ASTM 1994). This study was conducted within about 1 year based on several variables. All samples were gathered after backwash phase and during 0-17 h after filter operation. The maximum head loss for backwash phase in each filter was $160 \mathrm{~cm}(20 \mathrm{~cm}$ for system head loss and $140 \mathrm{~cm}$ for operation head loss).

\section{Statistical analysis}

To compare the efficiency of the media on turbidity removal (in different condition), statistical analyses of analysis of variance (ANOVA) and $t$ test were used $(P$ value $<0.05)$ (Berthouex and Brown 2002).

\section{Results and discussion}

Tables 3 and 4 show the outlet water turbidities in $30 \mathrm{~cm}$ and final depth of each filter, respectively. As can be seen, standard deviations of turbidity averages were high in lag and breakpoint operation phases, however, they were more proper in stable phase due to stability of filters operation and efficiency. Table 5 shows the removal efficiencies of turbidity in $30 \mathrm{~cm}$ and final depth of filter beds in the stable phase.

Table 3 Outlet water turbidities in $30-\mathrm{cm}$ depth of filter beds

\begin{tabular}{|c|c|c|c|c|c|c|c|}
\hline \multirow{3}{*}{$\begin{array}{l}\text { Inlet turbidity } \\
\text { (NTU) }\end{array}$} & \multirow{3}{*}{$\begin{array}{l}\text { Coagulant con. } \\
\text { (ppm) }\end{array}$} & \multirow{3}{*}{$\begin{array}{l}\text { Filtration rate } \\
(\mathrm{m} / \mathrm{h})\end{array}$} & \multirow{3}{*}{$\begin{array}{l}\text { Operation } \\
\text { time }(\mathrm{h})\end{array}$} & \multicolumn{4}{|c|}{ Outlet water turbidity (NTU) } \\
\hline & & & & \multicolumn{2}{|c|}{ Anthracite filter } & \multicolumn{2}{|l|}{ LECA filter } \\
\hline & & & & $\begin{array}{l}\text { During stable } \\
\text { phase }\end{array}$ & $\begin{array}{l}\text { During total } \\
\text { operation phase }\end{array}$ & $\begin{array}{l}\text { During stable } \\
\text { phase }\end{array}$ & $\begin{array}{l}\text { During total } \\
\text { operation phase }\end{array}$ \\
\hline \multirow[t]{3}{*}{10} & \multirow[t]{3}{*}{4} & 10 & 18 & $0.99 \pm 2.48$ & $2.79 \pm 3.73$ & $2.2 \pm 0.97$ & $3.33 \pm 2.63$ \\
\hline & & 15 & 11 & $1.54 \pm 2.77$ & $2.87 \pm 4.01$ & $1.96 \pm 1.08$ & $3.21 \pm 2.7$ \\
\hline & & 20 & 8 & $1.55 \pm 2.22$ & $3.07 \pm 3.72$ & $1.85 \pm 1.58$ & $3.29 \pm 3.03$ \\
\hline \multirow[t]{3}{*}{20} & \multirow[t]{3}{*}{8} & 10 & 9 & $0.69 \pm 2.4$ & $6.5 \pm 7.42$ & $1.75 \pm 0.65$ & $6.12 \pm 5.27$ \\
\hline & & 15 & 8 & $0.54 \pm 3.17$ & $7.07 \pm 7.95$ & $2.79 \pm 1.1$ & $6.17 \pm 5.02$ \\
\hline & & 20 & 6 & $0.56 \pm 3.17$ & $5.5 \pm 9.6$ & $2.74 \pm 0.52$ & $6.31 \pm 3.65$ \\
\hline \multirow[t]{2}{*}{30} & \multirow[t]{2}{*}{12} & 10 & 6 & $0.25 \pm 3.68$ & $8.4 \pm 9.83$ & $2.33 \pm 0.68$ & $6.45 \pm 5.75$ \\
\hline & & 15 & 5 & $1.58 \pm 4.23$ & $11.0 \pm 11.6$ & $2.85 \pm 1.85$ & $8.75 \pm 8.28$ \\
\hline
\end{tabular}


Table 4 Outlet water turbidities in final depth of filter beds

\begin{tabular}{|c|c|c|c|c|c|c|c|}
\hline \multirow{3}{*}{$\begin{array}{l}\text { Inlet turbidity } \\
\text { (NTU) }\end{array}$} & \multirow{3}{*}{$\begin{array}{l}\text { Coagulant con. } \\
\text { (ppm) }\end{array}$} & \multirow{3}{*}{$\begin{array}{l}\text { Filtration rate } \\
(\mathrm{m} / \mathrm{h})\end{array}$} & \multirow{3}{*}{$\begin{array}{l}\text { Operation } \\
\text { time }(\mathrm{h})\end{array}$} & \multicolumn{4}{|c|}{ Outlet water turbidity (NTU) } \\
\hline & & & & \multicolumn{2}{|l|}{ Anthracite filter } & \multicolumn{2}{|l|}{ LECA filter } \\
\hline & & & & $\begin{array}{l}\text { During stable } \\
\text { phase }\end{array}$ & $\begin{array}{l}\text { During total } \\
\text { operation phase }\end{array}$ & $\begin{array}{l}\text { During stable } \\
\text { phase }\end{array}$ & $\begin{array}{l}\text { During total } \\
\text { operation phase }\end{array}$ \\
\hline \multirow[t]{3}{*}{10} & 4 & 10 & 18 & $0.21 \pm 0.17$ & $0.06 \pm 0.1$ & $0.12 \pm 0.05$ & $0.16 \pm 0.14$ \\
\hline & & 15 & 11 & $0.18 \pm 0.19$ & $0.05 \pm 0.1$ & $0.09 \pm 0.05$ & $0.18 \pm 0.2$ \\
\hline & & 20 & 8 & $0.27 \pm 0.3$ & $0.01 \pm 0.15$ & $0.18 \pm 0.05$ & $0.31 \pm 0.23$ \\
\hline \multirow[t]{3}{*}{20} & 8 & 10 & 9 & $1.73 \pm 1.79$ & $0.20 \pm 0.47$ & $0.4 \pm 0.1$ & $1.51 \pm 1.53$ \\
\hline & & 15 & 8 & $2.26 \pm 1.86$ & $0.10 \pm 0.35$ & $0.42 \pm 0.07$ & $1.3 \pm 1.45$ \\
\hline & & 20 & 6 & $1.75 \pm 2.34$ & $0.12 \pm 0.82$ & $0.51 \pm 0.21$ & $1.79 \pm 1.59$ \\
\hline \multirow[t]{2}{*}{30} & 12 & 10 & 6 & $2.6 \pm 2.63$ & $0.06 \pm 0.33$ & $0.24 \pm 0.1$ & $1.82 \pm 1.54$ \\
\hline & & 15 & 5 & $2.72 \pm 3.44$ & $0.59 \pm 1.18$ & $0.62 \pm 0.26$ & $2.57 \pm 1.83$ \\
\hline
\end{tabular}

Table 5 Outlet water turbidity efficiencies in $30 \mathrm{~cm}$ and final depth of filter beds in stable phase

\begin{tabular}{llll}
\hline Filer type & $\begin{array}{l}\text { Depth } \\
(\mathrm{cm})\end{array}$ & $\begin{array}{l}\text { Inlet turbidity } \\
(\mathrm{NTU})\end{array}$ & $\begin{array}{l}\text { Efficiency } \\
(\%)\end{array}$ \\
\hline LECA filter & 30 & 10 & $79.97 \pm 1.79$ \\
& & 20 & $87.87 \pm 2.92$ \\
& 30 & $91.37 \pm 1.23$ \\
& \multirow{2}{*}{80} & 10 & $98.67 \pm 0.46$ \\
& & 20 & $97.77 \pm 0.30$ \\
Anthracite & 30 & 10 & $98.56 \pm 0.90$ \\
filter & & 20 & $75.12 \pm 2.75$ \\
& & 30 & $84.43 \pm 3.42$ \\
& & 10 & $86.82 \pm 1.30$ \\
& & 20 & $98.84 \pm 0.29$ \\
& & 30 & $97.29 \pm 1.22$ \\
& & & $97.48 \pm 2.00$ \\
\hline
\end{tabular}

Head losses of LECA and anthracite layers were $16.59 \pm 1.1$ and $25.5 \pm 1.45 \%$ (of total head losses of systems), respectively. These head losses were stable in different turbidities and filtration rates $(P$ value $<0.05)$.

Head losses consideration showed that head losses of LECA and anthracite layers with 40-cm depth were $16.59 \pm 1.1$ and $25.5 \pm 1.45 \%$ (of total head losses of systems), respectively. These head losses were changed slightly in different turbidities and filtration rates. These variations were $14.75 \pm 1.26$ to $17.68 \pm 2.2$ for LECA layer and $23.4 \pm 1.8$ to $26.99 \pm 1.98$ for anthracite layer.

Other indices for filter efficiency evaluation considered were the EPN and the PI which was calculated by multiplying the EPN to particle diameter (PD) (Eq. 1).

$\mathrm{PI}(\mathrm{N} \mu \mathrm{m})=\mathrm{PD}(\mu \mathrm{m}) \times \operatorname{EPN}(\mathrm{N})$

These indices were used, because, escaped particles from filter are related to the outlet water quality, while the inlet turbidity was stable. In other words, the less number and diameter of the escaped particles, the more removal efficiency of filters were achieved. Therefore, the EPN and PI were suitable indices. According to American drinking water standards (AWWA 2004), the allowable particles in drinking water are $50 / \mathrm{mL}$ with diameter limit of $2-10 \mu \mathrm{m}$. Thus, the PI is between 100 and $500 \mathrm{~N} \mu \mathrm{m} / \mathrm{mL}$. The average of the EPN is more than $300 / \mathrm{mL}$ corresponding to 99.99\% Giardia and Cryptosporidium removal. Therefore, unlike the turbidity and EPN indices, the PI index is suitable for filter efficiency determination. Table 6 shows simultaneous comparison of turbidity, the EPN and the PI for LECA and anthracite filters. As can be seen, turbidities and the EPN are in standard range while the PI is more than them.

Results of Table 5 show that anthracite and LECA layers, specially the first 30-cm depth of those, had considerable effects on turbidity removal (79.97 \pm 1.79 to $91.37 \pm 1.23 \%$ for LECA layer and $75.12 \pm 2.75$ to $86.82 \pm 1.3 \%$ for anthracite layer in stable phase). It seems that LECA layer efficiency was slightly more than anthracite layer in turbidity removal, although the one-way ANOVA test shows no significant differences between these layers efficiencies $(P$ value $<0.05)$ in turbidity removal. By comparison of different operating condition (turbidity and filtration rate) of LECA and anthracite layers by paired sample $t$ test, it was deduced that the LECA layer efficiency had significant differences with turbidity changes while filtration rate could not affect turbidity removal of this layer $(P$ value $<0.05)$. Besides turbidity, the filtration rate has also affected the efficiency of the anthracite layer in rates of 10 and $15 \mathrm{~m} / \mathrm{h}$. It means that although the LECA layer can be operated in different filtration rates without any efficiency failure, its efficiency may be decreased in different turbidities (10, 20 and 30 NTU). Mitrouli et al. (2008) have shown that the performance of 
Table 6 Simultaneous comparison of turbidity, particle number and new index for LECA and anthracite filters

\begin{tabular}{|c|c|c|c|c|c|c|c|c|}
\hline \multirow{2}{*}{$\begin{array}{l}\text { Inlet } \\
\text { turbidity } \\
\text { (NTU) }\end{array}$} & \multirow{2}{*}{$\begin{array}{l}\text { Filtration } \\
\text { rate }(\mathrm{m} / \mathrm{h})\end{array}$} & \multirow{2}{*}{$\begin{array}{l}\text { Operation } \\
\text { time (h) }\end{array}$} & \multicolumn{3}{|l|}{ LECA } & \multicolumn{3}{|l|}{ Anthracite } \\
\hline & & & $\begin{array}{l}\text { Outlet turbidity } \\
\text { during operation phase } \\
\text { (NTU) }\end{array}$ & $\begin{array}{l}\text { EPN } \\
(\mathrm{N} / \mathrm{mL})\end{array}$ & $\begin{array}{l}\mathrm{PI} \\
(\mathrm{N} \times \mu \mathrm{m})\end{array}$ & $\begin{array}{l}\text { Outlet turbidity } \\
\text { during operation phase } \\
\text { (NTU) }\end{array}$ & $\begin{array}{l}\text { EPN } \\
(\mathrm{N} / \mathrm{mL})\end{array}$ & $\begin{array}{l}\mathrm{PI} \\
(\mathrm{N} \times \mu \mathrm{m})\end{array}$ \\
\hline \multirow[t]{7}{*}{10} & 10 & 6 & 0.18 & 33 & 621 & 0.11 & 10 & 303 \\
\hline & 10 & 11 & 0.17 & 29 & 514 & 0.12 & 13 & 326 \\
\hline & 10 & 13 & 0.15 & 38 & 814 & 0.06 & 15 & 355 \\
\hline & 15 & 8 & 0.15 & 48 & 807 & 0.12 & 21 & 347 \\
\hline & 15 & 1 & 0.15 & 17 & 428 & 0.14 & 39 & 623 \\
\hline & 20 & 3 & 0.14 & 37 & 604 & 0.16 & 24 & 591 \\
\hline & 20 & 4 & 0.19 & 38 & 821 & 0.16 & 38 & 494 \\
\hline
\end{tabular}

Fig. 2 Outlet turbidities of the filters in 30-cm depths in different condition
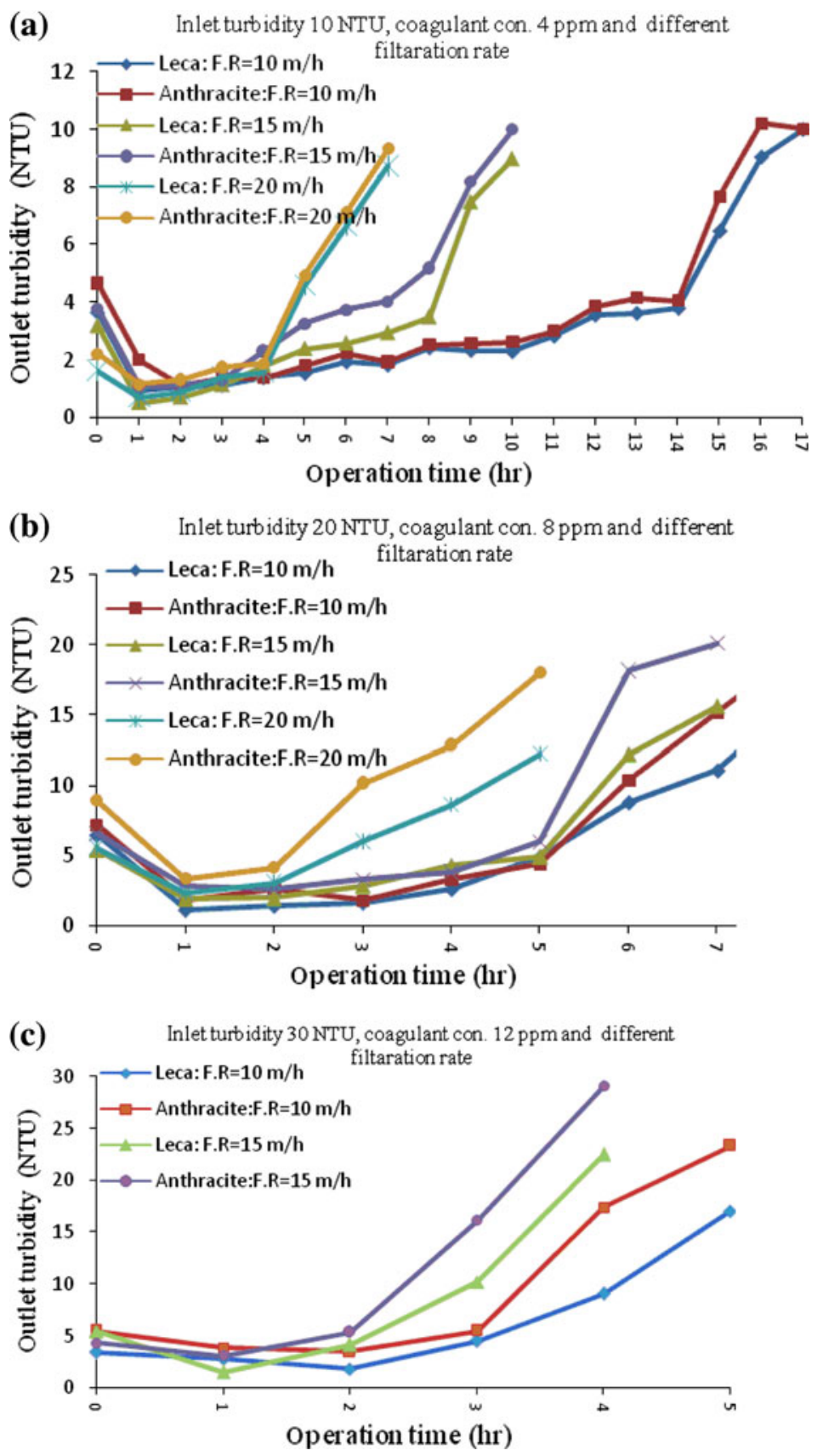
Fig. 3 Outlet turbidities of the whole depths of filter columns in different condition
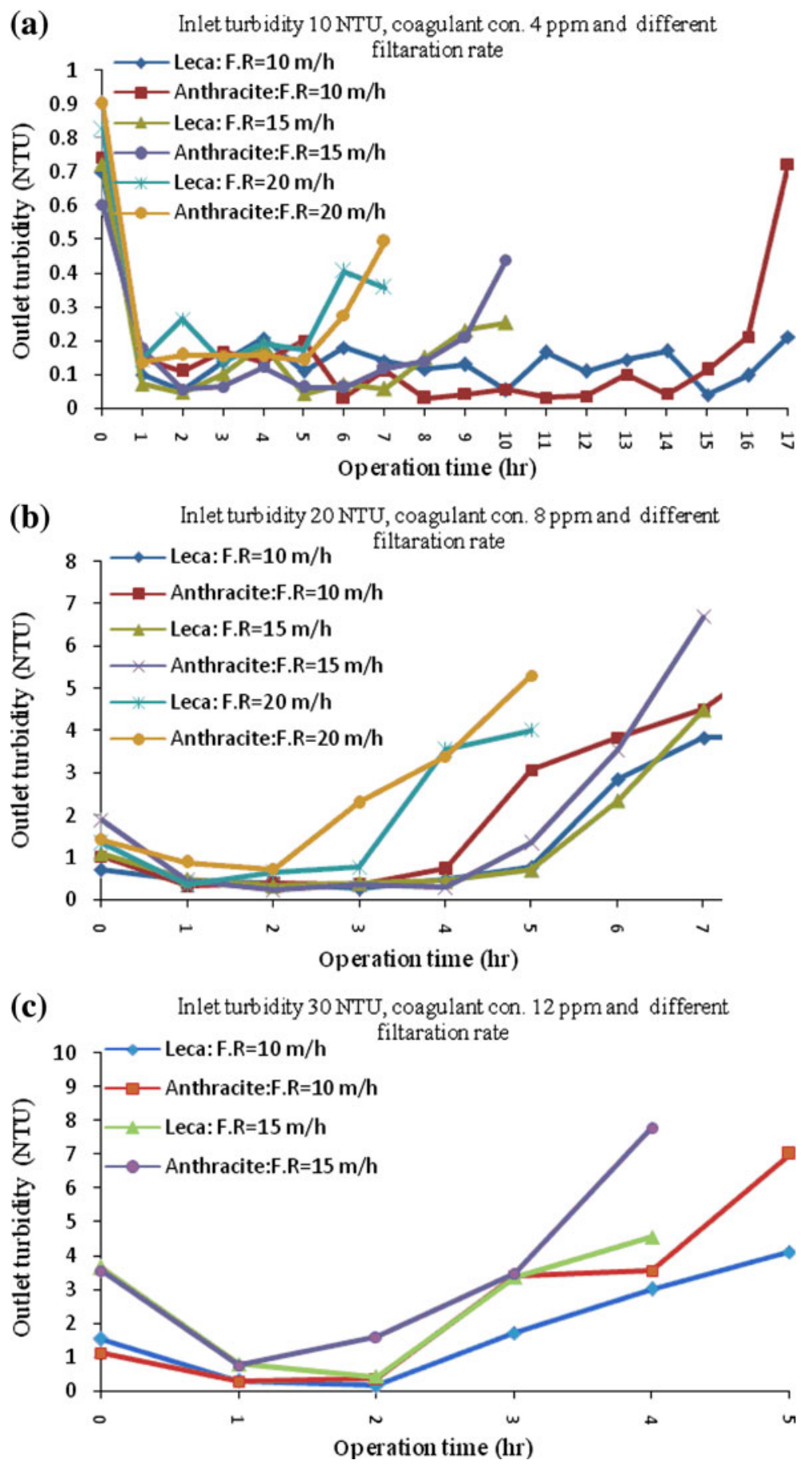

the anthracite layer for sea-water filtration, in the filtration rate of $5 \mathrm{~m} / \mathrm{h}$, was significantly better than that of $10 \mathrm{~m} / \mathrm{h}$. Furthermore, the turbidity removal in the total depth of two filter columns had not significant changes and the efficiency of the total system for mentioned phase was $97.77 \pm 0.30$ to $98.67 \pm 0.46 \%$ for the LECA column and $97.29 \pm 1.22$ to $98.84 \pm 0.29 \%$ for the anthracite column. These tables show the efficiency of silica layer and proportion of each layer in the turbidity removal. Hence,
LECA and anthracite layers play an important role in turbidity removal. However, the filtration cycle of the anthracite layer was broken after $22 \mathrm{~h}$ (head losses of $60 \mathrm{~cm}$ ) (Templeton et al. 2007).

Figures 2 and 3 illustrate outlet turbidities of each filter in $30 \mathrm{~cm}$ and whole depths of filters column in different conditions. These figures show that the stable phases of filter operation were decreasing when the filtration rates were increasing. Moreover, with increase in the inlet 
turbidity, the stable phases of filter operation decrease and outlet turbidities and lines slope increase.

Results of filters head losses in different condition of turbidities and filtration rates showed that with increasing operation period and filtration rate in stable turbidity, head losses were increased nonlinearly. As well, the LECA layer in comparison with the anthracite layer caused less head loss and more turbidity removal efficiency in the filter column. Hegazy (2008) reported that the LECA layer could be a proper media for filtration process, the performance of which is independent of the filtration rate.

Outlet turbidities, the EPN and the PI in whole depths of filter columns in different conditions are shown in Figs. 4 and 5 . In some cases, the outlet turbidity was in standard condition while the EPN was more than standards and it shows that the turbidity index was not enough for filter efficiency determination. These figures obviously show that while the outlet turbidity was in standard range, the EPN was not low and also diameter distribution of particles was inconsistent; thus, using the EPN without consideration to their diameter effect is useless.

The PI can be used as a suitable index. By analyzing the graphs, it can be concluded that with increase in the considered index, filters reached stable and breakpoint phases. Moreover, with increase or decrease in the EPN and the PI, filters reached the stable and breakpoint phases, respectively. However, when the outlet turbidity was in standard ranges, the PI may not be less than $300 / \mathrm{mL}$ and this condition shows again that the turbidity and the EPN were not solely enough for the determination of filter efficiency. The PI and its cumulative values were used for comparing LECA and anthracite filters' efficiencies (Fig. 6). It is

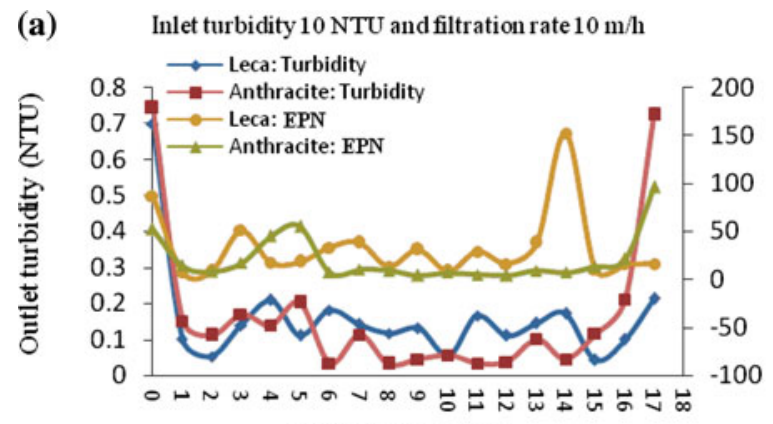

Operation time (hr)

(b) Inlet turbidity $10 \mathrm{NTU}$ and filtration rate $15 \mathrm{~m} / \mathrm{h}$

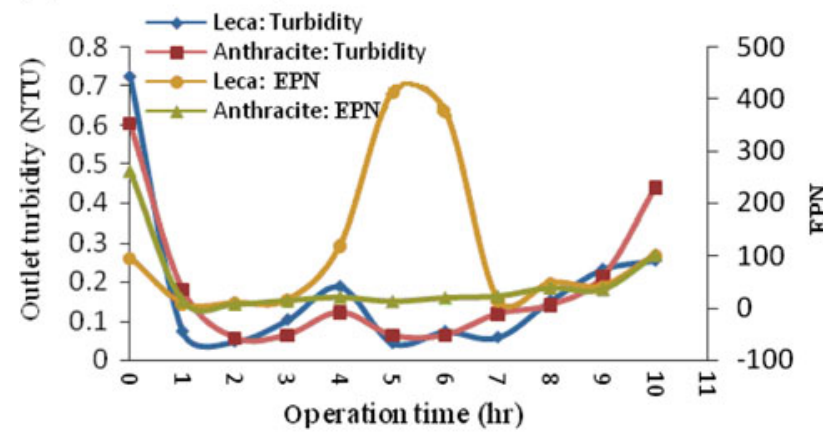

(c) Inlet turbidity $10 \mathrm{NTU}$ and filtration rate $20 \mathrm{~m} / \mathrm{h}$

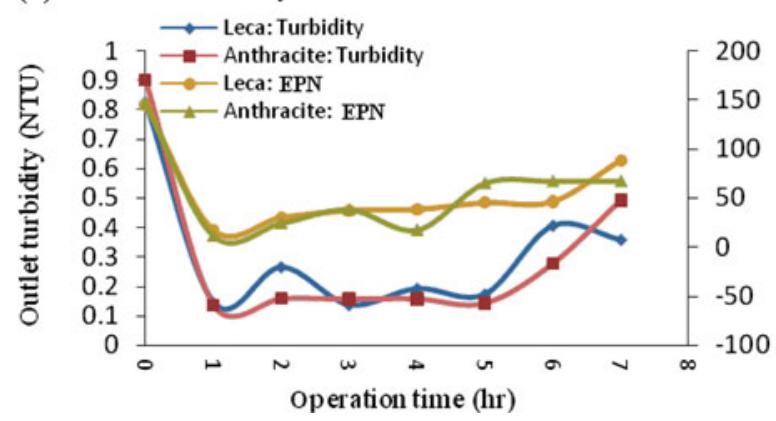

Fig. 4 Outlet turbidities and the EPN in whole depths of filter columns in different condition (a) Inlet turbidity $10 \mathrm{NTU}$ and filtration rate $10 \mathrm{~m} / \mathrm{h}$

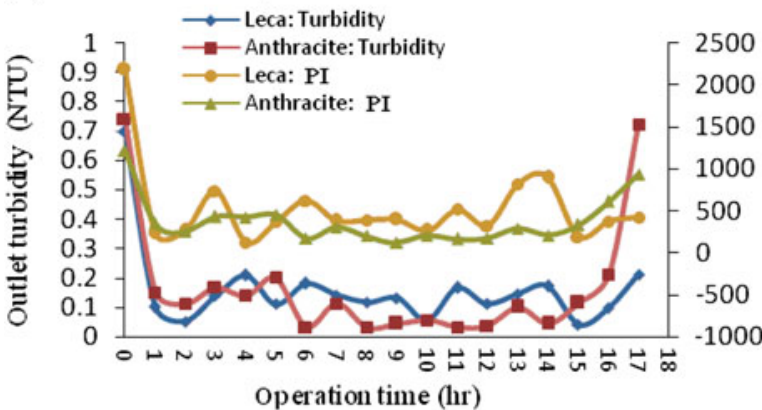

高

(b) Inlet turbidity $10 \mathrm{NTU}$ and filtration rate $15 \mathrm{~m} / \mathrm{h}$

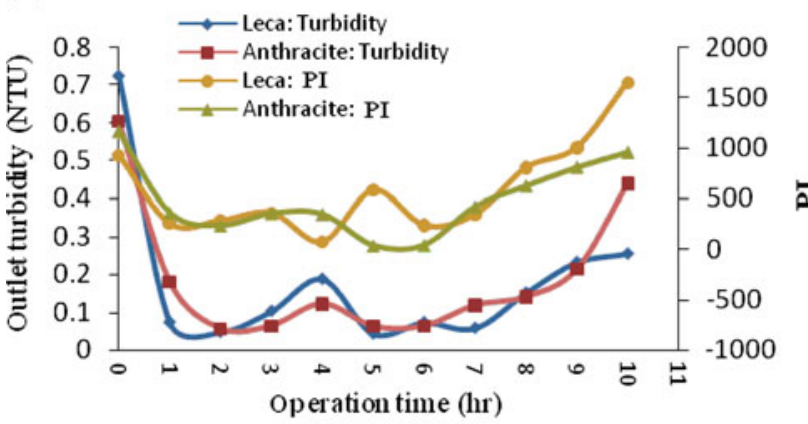

(c) Inlet turbidity $10 \mathrm{NTU}$ and filtration rate $20 \mathrm{~m} / \mathrm{h}$

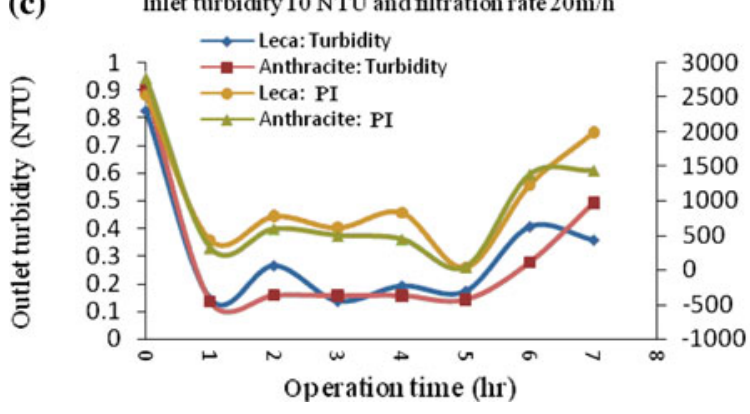

Fig. 5 Outlet turbidities and the PI in whole depths of filter columns in different condition 
(a) Inlet turbidity $10 \mathrm{NTU}$ and filtration rate $10 \mathrm{~m} / \mathrm{h}$ $\longrightarrow$ Leca: PI

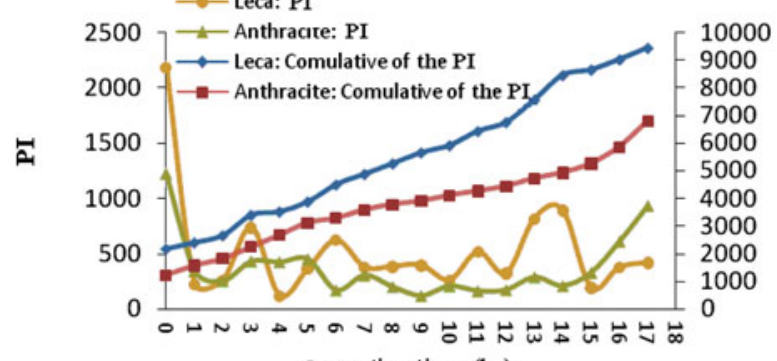

Operation time (hr)

(b) Inlet turbidity $10 \mathrm{NTU}$ and filtration rate $15 \mathrm{~m} / \mathrm{h}$

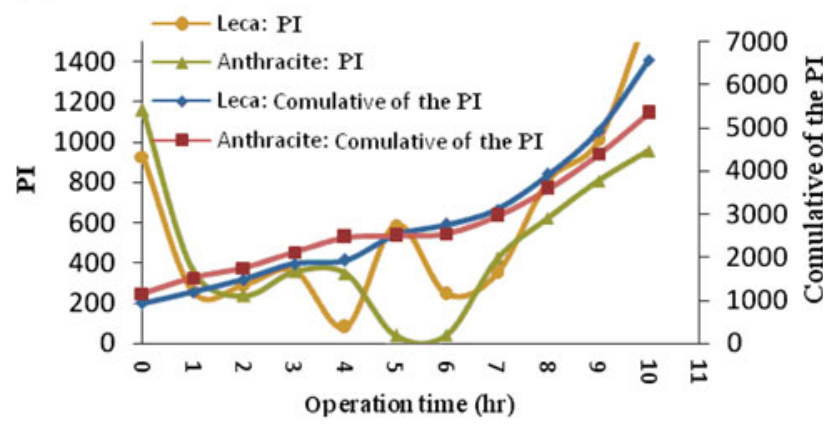

(c) Inlet turbidity $10 \mathrm{NTU}$ and filtration rate $20 \mathrm{~m} / \mathrm{h}$

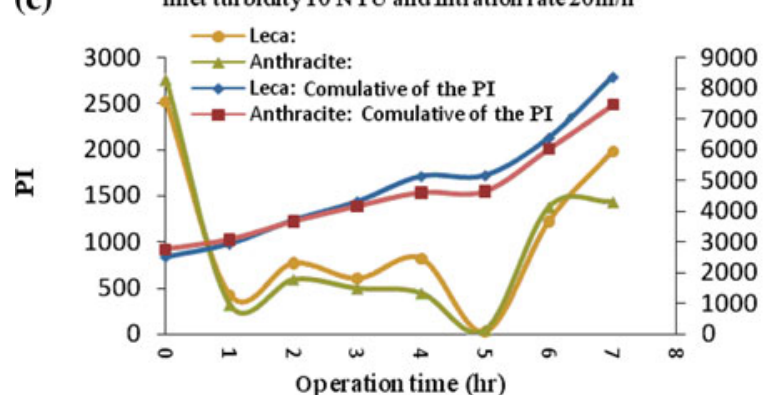

Fig. 6 The PI and its cumulative values in whole depths of filter columns in different condition

obvious that for lesser PI, higher filtration efficiency is obtained. As shown in Table 6, the turbidity and/or EPN may be in standard range while the PI is more than standards. Thus, it can be concluded the PI is suitable for determination of filter efficiencies.

\section{Conclusion}

Application of proper media for the filtration process of water-treatment plants and precise determination of their performance and efficiency has been considered. This study shows that the LECA-silica media had significant efficiency in turbidity removal in compare with anthracitesilica media, in different operating condition. The LECA layer was independent from filtration-rate effects and played the main role in turbidity removal. The PI index could be properly applied as a qualitative index for determining the efficiency of filters turbidity removal instead of the EPN and turbidity, due to its more precise changes during filtration period, and therefore, better determination of breakpoint phase of the filter.

Acknowledgments Authors highly appreciate of Power and Water University of Technology (PWUT) for their financial supports for this study (Grant number: WW8405).

\section{References}

Amiri H, Jaafarzadeh N, Ahmadi M, Martínez SS (2011) Application of LECA modified with fenton in arsenite and arsenate removal as an adsorbent. Desalination 272:212-217

APHA, AWWA, WEF (2005) Standard methods for the examination of water and wastewater, 21st edn. American Public Health Association, American Water Works Association and the Water Environment Federation, Washington, DC

ASTM (1994) Standard test method for turbidity of water, vol 11.01. American Society For Testing And Materials, Philadelphia

AWWA (2004) Water quality and treatment. Mcgraw-Hill Inc

Babu R, Chaudhuri M (2005) Home water treatment by direct filtration with natural coagulant. J Water Health 3:27-30

Baruth EE (2005) Water treatment plant design. Mcgraw-Hill Inc, New York

Berthouex PM, Brown LC (2002) Statistics for environmental engineers. Lewis Publishers, Florida

Brogowski Z, Renman G (2004) Characterization of opoka as a basis for its use in wastewater treatment. Pol J Environ Stud 13:15-20

Davis ML (2010) Water and wastewater engineering. Mcgraw-Hill Inc, New York

Devi R, Alemayehu E, Singh V, Kumar A, Mengistie E (2008) Removal of fluoride, arsenic and coliform bacteria by modified homemade filter media from drinking water. Bioresource Technol 99:2269-2274

El-Taweel GE, Ali GA (2000) Evaluation of roughing and slow sand filters for water treatment. Water Air Soil Pollut 120:21-28

Fuerhacker M, Haile TM, Monai B, Mentler A (2011) Performance of a filtration system equipped with filter media for parking lot runoff treatment. Desalination 275:118-125

Hammer MJ (2011) Water and wastewater technology. Prentice Hall

Hatt BE, Fletcher TD, Deletic A (2007) Treatment performance of gravel filter media: implications for design and application of stormwater infiltration systems. Water Res 41:2513-2524

Hegazy BE (2008) A simple technology for industrial wastewater treatment. J Appl Sci Res 4:397-402

Ho L, Grasset C, Hoefel D, Dixon MB, Leusch FDL, Newcombe G, Saint CP, Brookes JD (2011) Assessing granular media filtration for the removal of chemical contaminants from wastewater. Water Res 45:3461-3472

Johnston PR (1999) Pore-size distributions in filter media with graded densities. Filtr Separat 36:51-55

Kawamura S (2000) Integrated design of water treatment facilities. Wiley, New Jersey

Malakootian M (2009) Removal of heavy metals from paint industry's wastewater using leca as an available adsorbent. Int J Environ Sci Technol 6:183-190

Melin ES, Bohne RA, Sj $\varphi$ vold F, Degaard H (2000) Treatment of ozonated water in biofilters containing different media. Water Sci Technol 4-5:57-60

Mitrouli ST, Yiantsios SG, Karabelas AJ, Mitrakas M, Follesdal M, Kjolseth PA (2008) Pretreatment for desalination of seawater 
from an open intake by dual-media filtration: pilot testing and comparison of two different media. Desalination 222:24-37

Mitrouli ST, Karabelas AJ, Yiantsios SG, Kjølseth PA (2009) New granular materials for dual-media filtration of seawater: pilot testing. Sep Purif Technol 65:147-155

Moazed H, Viraraghavan T (2002) Coalescence/filtration of an oil-inwater emulsion in a granular organo-clay/anthracite mixture bed. Water Air Soil Pollut 138:253-270

Pawlowicz MB, Evans JE, Johnson DR, Brooks RG (2006) A study of the efficacy of various home filtration substrates in the removal of microcystin-lr from drinking water. J Water Health 4:99-107

Remize PJ, Laroche JF, Leparc J, Schrotter JC (2009) A pilot-scale comparison of granular media filtration and low-pressure membrane filtration for seawater pretreatment. Desalination Water Treat 5:6-11

Roque-Malherbe RM (2007) Lead, copper, cobalt and nickel removal from water solutions by dynamic ionic exchange in leca zeolite beds. Int J Environ Pollut 31:292-303
Taghizadeh MM, Torabian A, Borghei M, Hassani AH (2007) Feasibility study of water purification using vertical porous concrete filter. Int J Environ Sci Technol 4:505-512

Tansel B, Vinal F (2005) Enhancement of media filter performance with coagulant use for treatment of diesel oil contaminated surface water. Desalination 173:69-76

Templeton MR, Andrews RC, Hofmann R (2007) Removal of particle-associated bacteriophages by dual-media filtration at different filter cycle stages and impacts on subsequent UV disinfection. Water Res 41:2393-2406

Williams GJ, Sheikh B, Holden RB (2007) The impact of increased loading rate on granular media, rapid depth filtration of wastewater. Water Res 41:4535-4545

Zouboulis A, Traskas G, Samaras P (2007) Comparison of single and dual media filtration in a full-scale drinking water treatment plant. Desalination 213:334-342 